This article was downloaded by: 10.3.98.93

On: 21 Jan 2019

Access details: subscription number

Publisher: Routledge

Informa Ltd Registered in England and Wales Registered Number: 1072954 Registered office: 5 Howick Place, London SW1P 1WG, UK

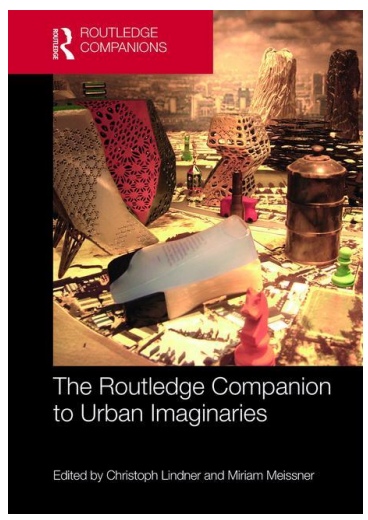

\title{
The Routledge Companion to Urban Imaginaries
}

\author{
Christoph Lindner, Miriam Meissner
}

Thirsty cities

Publication details

https://www.routledgehandbooks.com/doi/10.4324/9781315163956-2

Dora Apel

Published online on: 18 Oct 2018

How to cite :- Dora Apel. 18 Oct 2018, Thirsty cities from: The Routledge Companion to Urban Imaginaries Routledge

Accessed on: 21 Jan 2019

https://www.routledgehandbooks.com/doi/10.4324/9781315163956-2

\section{PLEASE SCROLL DOWN FOR DOCUMENT}

Full terms and conditions of use: https://www.routledgehandbooks.com/legal-notices/terms

This Document PDF may be used for research, teaching and private study purposes. Any substantial or systematic reproductions, re-distribution, re-selling, loan or sub-licensing, systematic supply or distribution in any form to anyone is expressly forbidden.

The publisher does not give any warranty express or implied or make any representation that the contents will be complete or accurate or up to date. The publisher shall not be liable for an loss, actions, claims, proceedings, demand or costs or damages whatsoever or howsoever caused arising directly or indirectly in connection with or arising out of the use of this material. 


\title{
Thirsty cities
}

\section{Who owns the right to water?}

\author{
Dora Apel
}

\section{Human right or corporate right?}

Is access to clean water a basic human right or is water a commodity to be bought and sold by corporations? Should water be part of a democratic public commons or should water distribution be run like a business that values the bottom line over public health and human lives, denying water to those who cannot afford it? As clean water becomes increasingly scarce, water access and control become more urgent. Globally, the scale of ecological dispossession through corporate control of water, combined with chemical agriculture, the destructive diversion of water through large dam projects, and the climate chaos produced by greenhouse gas emissions, has led to the creation of deserts, the depletion of rivers and lakes, widespread disease, battles and wars (often masked as ethnic or religious conflicts), and a massive refugee crisis. Environmental activist Maude Barlow asserts that "The global water crisis has become the most powerful symbol of the growing inequality in our world", based on the three fundamental water crises that pose a threat to the survival of the world's populations: dwindling freshwater supplies, inequitable access to water, and the corporate control of water (Barlow, 2007: 1, 142). Yet to many, the global water crisis remains largely invisible.

As case studies, Flint and Detroit provide object lessons in how we use water, distribute it, contaminate it, and waste it, while also demonstrating that water crises are not only local but have wide-ranging implications. They provide object lessons about problems whose solutions hinge on whether we view water as a free right and human commons or as a corporate right. Although it is the poor and marginalized in declining cities and regions who suffer most at this point, ultimately, the effects of water scarcity will cross race and class lines, countries and continents, and once water has been depleted, it cannot be replenished.

Approximately an hour apart in the state of Michigan, Detroit and Flint are impoverished majority black cities that have become emblematic of urban centers seen by the neoliberal state as profit-making opportunities with expendable populations. The state's Republican Governor Rick Snyder suspended democracy in both cities when he voided the powers of the elected mayors and city councils and instead appointed emergency managers to run the cities, who were accountable only to himself. In Detroit, the emergency manager (EM) turned off water for 20,000 residents before giving control back to the mayor (who then 
continued the water shutoffs). In Flint, the EM recommended switching the city's water source to the polluted and highly corrosive Flint River, which caused massive damage to an already crumbling infrastructure, an outbreak of Legionnaire's disease, and the lead poisoning of the water, potentially exposing the city's 100,000 residents, with especially devastating effects on its children.

\section{Flint: public health and the bottom line}

Shortly after the EM switched Flint's drinking water source from the Detroit Water and Sewerage Department (DWSD) to the Flint River in March 2014, residents began complaining that the dirty brown and foul smelling water coming out of their taps caused chemical burns and skin rashes, caused their hair to fall out, and made them ill in other ways. The Michigan Department of Environmental Quality (DEQ) and other officials repeatedly and falsely reassured city residents for eighteen months that the water was safe for drinking, cooking, and bathing. How could this happen?

Flint officials decided to draw water from the Flint River rather than the DWSD while the new Karegnondi pipeline connecting Genesee County to Lake Huron was built, calculating that they would save about five million dollars. The cost for the Karegnondi (from the Petan Indian language meaning "lake" and an early name for Lake Huron) pipeline was calculated at $\$ 285$ million and the entity in charge of building it was the quasi-public Karegnondi Water Authority (KWA). The cost of Flint's share of the new pipeline was $\$ 85$ million, a price the bankrupt city could not pay.

Jeff Wright, the Genesee County drain commissioner and KWA CEO, spearheaded the drive to build the new pipeline. Wright argued that it would save Flint money because the DSWD was price-gouging the city: "Detroit charged whatever Detroit felt like charging for drinking water, and our community was forced to pay whatever it cost" (Guyette, 2017). As Curt Guyette (2017), an investigative reporter for the ACLU of Michigan, points out, Wright's complaint ignored the fact of Michigan law, which requires public water departments to charge municipalities only what it costs to treat and deliver water to its customers. Thus, like most public utilities, the DWSD is highly regulated and prohibited from making a profit. Where there are disputes over costs and reasonable rates, the DWSD may be challenged in court. The mayor of Flint at the time, Dayne Walling, was chair of the KWA board, and the governor appointed a former interim mayor as Flint's EM. Both strongly supported the KWA pipeline. Were they acting as watchdogs for the city or were they, along with KWA CEO Jeff Wright, seeking ways to secure political influence?

The KWA did not need Flint's participation to build the new pipeline, but it did need the city's approval to increase the diameter of the pipeline. In this one instance, the EM gave power back to the mayor and city council in a ceremonial vote for widening the pipeline, hoping this would prevent any future court challenges. Although they expected a quick decision, the process took more than a year. During this time, the governor asked the DWSD to come up with a new cost-saving proposal. "That proposal, according to the DWSD", writes Guyette (2017), "would save Flint and the Genesee County more than $\$ 900$ million as compared to the KWA alternative over the 30-year contract period".

Yet the new Flint EM flatly rejected the offer. Despite the prevailing narrative that Flint was bankrupt and switching water sources to save money, the EM dismissed the costsaving proposal by the DWSD that undermined the rationale for the switch. In addition, no one addressed the problem of Flint not having the money to pay its $\$ 85$ million share of the KWA pipeline. It appears, then, that the switch was not about saving money at all; 
instead, it seems intended to fill the campaign coffers of the politicians who supported the new pipeline by the private companies that would build it.

The decision about where Flint would get its water ultimately rested with the Michigan Department of Treasury. Despite the fact that no plan existed for financing the KWA option, or that the DWSD plan was cheaper, the Treasurer accepted the EM's recommendation to proceed with the KWA. When officials finalized the KWA agreement, the contract stipulated that Flint use the river as a temporary water source until the KWA water became available.

The first problem following the switch to the Flint River was that the water was infested with bacteria such as $e$-coli derived from fecal matter, and other toxins. Chlorine dumped into the water to deal with this problem then caused the production of cancer-causing chemicals called trihalomethanes (TTHMs), which affect the liver and kidneys (Democracy Now!, 2016). A deadly outbreak of Legionnaires' disease, which is caused by a water-borne bacteria, spread throughout the city, killing at least twelve people and affecting seventy-eight more (DeVito, 2017). While this was occurring, the river water, to which the city had added no anticorrosive, proceeded to corrode Flint's aging water pipes and to poison the drinking water with high levels of lead. In one home, an EPA manager detected lead levels seven times greater than the EPA's acceptable limit of 15 parts per billion. A Virginia Tech research team found that $40 \%$ of Flint homes had elevated levels of lead, with some homes at 13,200 parts per billion. But the DEQ expressed skepticism about the study to the Flint Journal.

Lead is a powerful neurotoxin that affects every system in the body and is especially harmful to pregnant women and children, where it can cause irreversible developmental delays because of damage to developing brains and nervous systems. In 2015, a research team at a local health center found that the proportion of children with elevated lead levels in their blood had nearly doubled since the water switchover, affecting around 9000 children under the age of six (Moore, 2016; NOVA, 2017).

Finally, in October 2015, Snyder signed a bill appropriating $\$ 9.35$ million, almost double the alleged "savings" of switching to river water in the first place, to reconnect the city to the Detroit water system. In the following months, both the city mayor and Snyder declared a state of emergency, the National Guard was mobilized to distribute bottled water, and a federal investigation began.

The corrosion of the city's lead water pipes would not have occurred if an anticorrosive had been added to the water, as required by federal law for large municipal systems. Why did the DEQ fail to add this crucial and inexpensive corrosion control chemical? At first, officials claimed there was an anti-corrosive plan, then that they had misunderstood the federal law, and finally that they were concerned an anti-corrosive would foster bacteria (Kaffer, 2016; NOVA, 2017). The DEQ knew there was a problem with lead contamination because they consistently tried to manipulate water safety tests by avoiding homes that had already tested high for lead and instructing city residents to flush their lines before collecting water samples, which would dilute the lead readings (NOVA, 2017).

The reason for the failure to add corrosion control finally became clear in testimony at a legislative hearing in March 2016. A reporter explained, "When Flint began to pump drinking water from the Flint River, the city's water treatment plant wasn't capable of adding corrosion control treatment, not without equipment upgrades the broke city couldn't afford" (Kaffer, 2016). Thus, the city switched its water source to the highly corrosive river knowing it could not afford to update the water treatment plant to provide corrosion control. In order to claim that the switch would save money, officials omitted the cost of updating the water treatment plant from the financial calculations. That cost 
has been estimated at $\$ 108$ million, in addition to the $\$ 85$ million (Fonger, 2017). This deliberate evasion and the collusion of the DEQ clearly suggests motives for the switch other than saving money or safeguarding public health.

In February 2015, Flint officials hired Veolia North America, a division of the French conglomerate that is the largest private water company in the world, to conduct a study of the city's water for $\$ 40,000$. While making a series of minor recommendations, Veolia announced in its report the following month that the water quality was "in compliance with State and Federal regulations", including nothing about corrosion or elevated lead levels, and thereby reinforcing the position of the DEQ and city officials (Veolia, 2015). Veolia afterwards proposed more extensive work for an estimated \$1.8 million, which the city declined (Smith and Bosman, 2016).

Cities cannot be run like corporations. To thrive, they must sustain the life and wellbeing of the community through access to essential resources like clean water and services such as education and health care. To run the city as a corporation and focus exclusively on the bottom line means sacrificing residents seen as "surplus" and "expendable" - people who may therefore be allowed to suffer slower or faster deaths from the harmful effects of poisoned water. Not just in Flint, but also in other cities across the nation, state and local officials have compromised the welfare of citizens. According to a report by the Natural Resources Defense Council (Khan, 2016), more than 18 million Americans received their drinking water from systems with lead violations in 2015. This is a conservative estimate and the number is actually thought to be higher, because many cities that are gaming the system and avoiding corrosion control, including Flint, are not entered into the EPA's database. Moreover, enforcement is lax, further helping to create unsafe drinking water conditions for millions of people. Nonetheless, the 18 million who drank lead-contaminated water are part of a larger estimate of 77 million people served by drinking water systems with other contaminants, including arsenic and dangerous bacteria (WJBD, 2017). About $70 \%$ of these people live in smaller cities and rural communities, leading to a two-tiered system of inequality that has only worsened under the Trump administration as cuts to the EPA cause cuts to drinking water programs and further encourage privatization and other cost-cutting measures.

The buying of political influence that helped trigger the Flint fiasco was revealed in an ACLU analysis of contributions to the 2016 political campaign by KWA CEO Jeff Wright for the position of Genesee County drain commissioner. The study shows that of the nearly $\$ 270,000$ he raised, at least $\$ 188,000$, or roughly $70 \%$, came from political action committees and employees of companies doing business directly with KWA or working on the pipeline in some capacity. One of Wright's biggest contributors was a Houstonbased engineering and project management firm that was one of KWA's primary contractors and helped conduct a 2009 study asserting the value of leaving the Detroit system and building its own pipeline. This company, along with other firms involved in the study, helped build the KWA pipeline, which was completed in 2017 (Guyette, 2017).

The tragedy of Flint is that it was an avoidable and knowing failure of government, produced by a combination of greed, political power grabbing, and indifference to the public health and safety of the poor and majority black city. Only a few months after the switch, when General Motors factory executives complained to Governor Snyder that the river water was corroding their car parts when washed on the assembly line, Snyder quietly spent $\$ 440,000$ to switch the plant back to Lake Huron (DWSD) water, while keeping Flint's residents on the corrosive river water (Moore, 2016).

Appointed Flint city officials, the DEQ, and the State of Michigan are all responsible for the fiasco, along with the EPA's Michigan regional administrator, who colluded in the 
disaster and has since resigned, plus the federal EPA, which also was complicit and responded too slowly. Ultimately, however, responsibility lies at the feet of Governor Snyder and the neoliberal ideology he upholds. After taking office in 2011, Snyder got the Republican legislature to award the wealthy and corporations enormous tax breaks, and then slashed public services such as schools, welfare, pensions, and safe drinking water to compensate for the lost revenue. It was Snyder who suspended democracy for four years and put Flint's fate in the hands of a series of appointed emergency managers whose job was to do what seemed cheapest, most expedient, and corporate-friendly. And it was Snyder who prioritized removing environmental safeguards: a 2012 statement entitled "Energy and the Environment" announced the elimination of more than 100 environmental regulations and cuts to staff levels at the DEQ and other "quality of life" agencies, in advance of similar appalling policies under the Trump administration.

Structural racism is also clearly at work (see Hammer, 2016). The Michigan Civil Rights Commission, which spent nearly a year investigating the crisis to see if racism played any role in the fiasco, issued a report determining that in a black-majority city with a poverty rate of $40 \%$, where democracy was curtailed and replaced by state-appointed emergency managers, racism and political influence-buying took precedence over serving the public good. The Commission wrote that such a crisis could not have occurred in affluent white Michigan cities, and asserted, "The lack of political clout left the residents with nowhere to turn, no way to have their voices heard" (Guyette, 2017). The role of structural racism in placing profit above the welfare of citizens is increasingly visible across the nation as it becomes increasingly destructive.

Flint residents fought back, however, with protests, citizen journalism, a new mayor, and a massive resident testing project, which turned the Flint disaster into a national scandal and brought renewed attention to the problems of clean water, official malfeasance, and lead poisoning.

In June 2016, new Flint Mayor Karen Weaver announced that the city was legally bound to the KWA contract despite the fact that a 2016 analysis of Flint water rates predicted that water bills for the city's residents, already among the highest in the nation, would double by 2022 under KWA. However, ten months later Weaver announced support for a plan to stay permanently with the Great Lakes Water Authority (GLWA), who had served as Flint's temporary water source after the city abandoned river water. The GLWA took over the DWSD regional water structure during the Detroit bankruptcy and became the provider of wholesale water and sewer services to member communities in Southeast Michigan in 2017. This new plan would reportedly save $\$ 1.8$ million annually over the life of a new thirty-year contract compared to staying with KWA (WXYZ, 2017). It took the city council another seven months to approve the plan because members were concerned that it would keep high water rates in place for residents for years. The truth is that, no matter which system is in place, water rates far exceed the national average.

The Flint water crisis is a warning about what is at stake when cities lose democratic control over their resources. By some estimates, it will cost $\$ 1.5$ billion to upgrade the entire system and provide services to those affected by lead poisoning (NOVA, 2017). Far from saving money for the city of Flint, the real costs of this catastrophe in financial terms are exponentially higher than any alleged savings ever could have been, and in human terms the cost is incalculable. Although Flint returned to the regional system that provided clean water for nearly fifty years in 2015 , city water still must be filtered for it to be safe to drink while the corroded lead service lines are replaced, and many are still afraid to use the water. There are also major problems with the city water mains, which leak 40 to $50 \%$ of the 
treated water that is pumped into them, and there are 20,000 lead service lines corroded by the river that need to be replaced, a process that will take years. Many residents stopped paying for their poisoned water, but controversy arose again when the city warned 8000 homeowners that tax liens would be placed on their homes if they were more than six months behind on their water accounts, making them vulnerable to home foreclosure (Delaney, 2017). Despite the continued need for water filters, the water was officially declared safe in 2017 (although no blood level of lead is safe), four years after the switch to river water.

Four government officials, one from the city of Flint, two from the DEQ, and one from the EPA, resigned over the mishandling of the crisis, and one more DEQ staff member was fired. Investigations continue at the federal, state, and local levels, and so far fifteen current and former state and local officials have been criminally indicted in connection to the disaster. Five of them have been charged with involuntary manslaughter in connection with the deaths from Legionnaire's disease, including the head of the state's health department, who did not warn the public about increases in the disease for a year after he knew about it and said, "Everyone has to die of something" (Atkinson and Davey, 2017). Four officials, including two of the city's former emergency managers, have been criminally charged with using false pretenses to obtain the loan needed by the city to finance its portion of the KWA option (Guyette, 2017). The Michigan attorney general is suing Veolia, as well as the company Lockwood, Andrews, and Newnam, which had been hired to advise the city about the switch in water sources. Nationally, environmental activists and the Massachusetts attorney general have accused Veolia of violations that include polluting waterways and overbilling customers, leading to lawsuits in courts around the country (Smith and Bosman, 2016).

In a powerful visual statement about race and second-class citizenship, New Orleansbased artist Ti-Rock Moore's artwork Flint depicts a water fountain with a constant stream of brown running water under a plaque that says "Colored". It was displayed at the international art competition ArtPrize in Grand Rapids, Michigan (20 September - 8 October 2017). Recalling the segregated water fountains of the Jim Crow era and the brutal inequality that segregation signified, Moore's work poignantly evokes the long legacy of American racist oppression in the poisoned water of the majority black city of Flint.

\section{Detroit shutoffs: prelude to privatization?}

The DWSD has not been immune to corruption. Suburban leaders have long criticized the DWSD for its annual rate increases and what many considered questionable contracting practices. In the 1980s, the head of the water department was imprisoned for taking bribes from a sludge-hauling company. More recently, department head Victor Mercado, who was appointed by former Mayor Kwame Kilpatrick, pleaded guilty to illegally steering contracts to a crony of Kilpatrick's in one of the largest corruption scandals in the city's history.

In March 2014, when Flint left the Detroit water system, the DWSD asserted that half of its 323,000 accounts in Detroit were delinquent and began turning off water for up to 3000 residents every week while EM Kevyn Orr requested proposals from private water companies interested in the DWSD (Gaist, 2014). The following September, the EM and federal bankruptcy mediators constructed a deal in which the DWSD was forced to lease its regional water infrastructure to the GLWA as part of a restructuring plan that also undermined unions, eliminated jobs, and reduced city pensions. The EM used the 


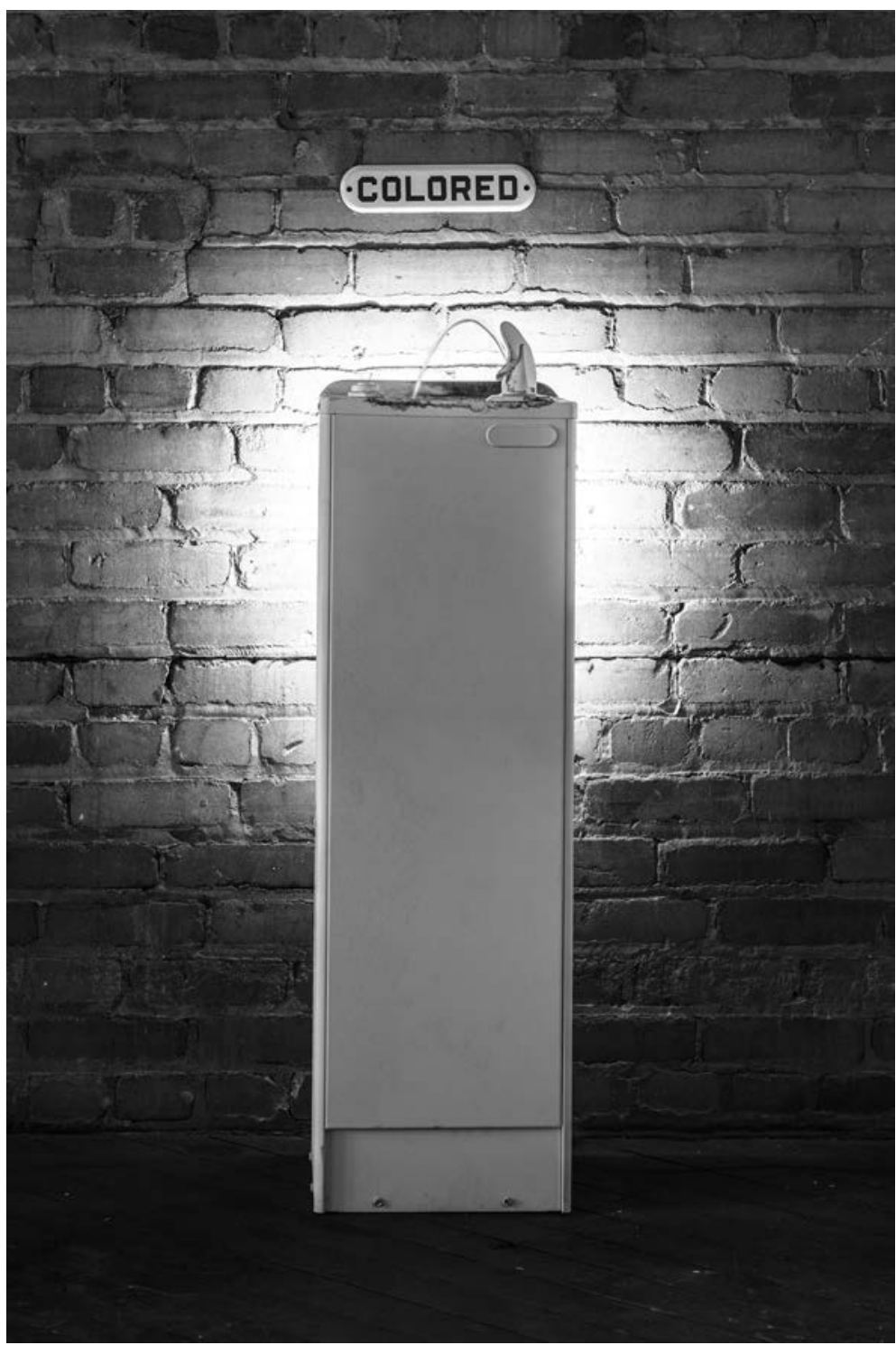

Figure 2.1 Ti-Rock Moore, Flint, 2016. Photo courtesy of the artist.

bankruptcy crisis to engineer the transfer of control of Detroit's water out of the city's hands in an action that may be read as a move toward the privatization of water, a policy supported by the Obama administration through the Water Resources Reform and Development Act of June 2014. This act dismantles restrictions on private investment in public utilities contained in the Clean Water Act and other federal legislation. The new act encourages financially strapped cities to enter "public-private partnerships" as federal and state funding for infrastructure declines (White, 2014). Public-private partnerships, while 
suggesting accountability, actually disguise and promote the privatization of public services. Obama's appointee at the EPA, who was complicit in covering up the lead poisoning of Flint residents, pushed for the privatization of essential social services, from public education to water systems (Brewer and White, 2016).

Under the regional authority agreement signed by Detroit Mayor Mike Duggan and three area counties, the GLWA has a forty-year lease for pipelines servicing suburban communities, at a cost of $\$ 50$ million per year. A six-member board of appointed officials makes decisions on water rates, contracts, labor agreements, and the privatization of services. The agreement overrides Detroit City Council's right to approve privatization of any portion of the water system, which, according to the City Charter, also must be approved by a majority of city voters in a regular or special election (White, 2014). By superseding these provisions, the new arrangement allows the future privatization of the GLWA at the mandate of an unelected board.

Like Flint's EM, Orr then contracted Veolia North America to recommend costsavings for Detroit's water system. This raises more critical questions. Is it a coincidence that pulling Flint out of the Detroit water system and depriving the DWSD of a large share of revenue helped cause the crisis that justified creating the GLWA and calling in Veolia? Is it a coincidence that Veolia is a major client of the Jones Day global law firm for which Orr works? Is it a coincidence that when Veolia was called in, water already had been shut off for nearly 20,000 households? Was this an attempt to eliminate "bad debt" and clear the way for refinancing and privatization, as many observers have suggested? Under Victor Mercado, who had previously worked for the private water company Thames Water North America, the DWSD shut off water for 40,000 people.

Many of the water cutoffs impacted children, allowing child welfare authorities to remove them from their homes, since working utilities in all homes with children are legally required. The water shutoffs left everyone, including the sick, without water to drink, without toilets, and without the ability to cook or bathe. No such cutoffs were implemented for large corporations and institutions, such as the Red Wings' hockey arena and the Ford football stadium, which were also delinquent on their bills, and thousands of vacant and abandoned buildings with water often gushing through broken pipes (Apel, 2015: 32).

A recent study conducted by researchers from Henry Ford Health System's Global Health Initiative (Plum et al., 2017) found a significant relationship between water shutoffs imposed by the City of Detroit and water-related illnesses experienced by a sample of Henry Ford Hospital patients, including skin and soft tissue infections and water-borne bacterial infections. Researchers analyzed data from more than 37,000 cases of water-borne illness for over a year starting in January 2015, which was then compared with a list of Detroit addresses whose water had been shut off. Even accounting for the effects of poverty, the study shows a clear connection between water-related illnesses and shutoffs.

United Nations investigators denounced the water shutoffs as a human rights violation, asserting, "Disconnections due to non-payment are only permissible if it can be shown that the resident is able to pay but is not paying. In other words, when there is genuine inability to pay, human rights simply forbids disconnections" (OHCHR, 2014). The city maintained it was responding to unpaid bills, but this turned out not to be entirely true, as even residents with up-to-date bills had their water shut off. Matthew Kovac (2015) notes that Detroit officials did not know exactly whose water they were shutting off, but, like 
banks that engaged in wrongful home foreclosures when they saw an opportunity to seize people's homes, they did not really care. Instead, they saw an opportunity to drive out low-income African Americans in order to clear the way for urban "development" and an influx of young white professionals, in a form of "hyper-gentrification" (see Apel, 2015: 31-3). As environmentalist Martin Lukacs observes,

... more than half of the city's commercial and industrial users are also owing - a sum totaling $\$ 30$ million. But no contractors have showed up on their doorstep. The targeting of Detroit families is about something else. It is a ruthless case of the shock doctrine - the exploitation of natural or unnatural shocks of crisis to push through pro-corporate policies that couldn't happen in any other circumstance.

(Nichols, 2014)

In response to growing national pressure over the mounting Detroit water crisis, fullscale media coverage, and a series of protest actions in Detroit, including a mass protest organized by National Nurses United, the largest labor union of registered nurses in the country, EM Orr finally announced a moratorium on shutoffs and relinquished control over the DWSD to the city's Mayor Duggan. Duggan himself, however, also has a history of supporting privatization, having overseen the sale of the nonprofit Detroit Medical Center to a for-profit hospital conglomerate in Virginia. Not surprisingly, water cutoffs eventually continued under Duggan.

Many who have bought inexpensive homes in Detroit have unwittingly inherited responsibility for water bills amounting to thousands of dollars. Despite pledges by city officials that water shutoffs would decline, they instead rose by $18 \%$ in 2016 , denying water to an additional 27,000 Detroit homes, a ratio of one in five. By the end of 2017, Detroit had shut off water to more than 100,000 homes (Kurth, 2017). Moreover, residents who cannot afford increases in their water bills have been further threatened with foreclosure through liens on their homes, like many Flint residents. Critics also note the intensification of the crisis under the city's " $10 / 30 / 50$ " payment plan:

[T]hose delinquent on their water bills are required to pay 10 percent of the overdue bill up front, with the remainder spread over a 24-month period on top of the regular already-unaffordable monthly bill. [I]n a city with an official poverty rate of 40 percent, avoiding a shutoff means increasing one's monthly payments for two years. City residents already pay water bills that are nearly twice the national average and this year [2015] rates went up another 3.4 percent for water and 16.7 percent for sewerage! This plan is a mathematical algorithm designed to suck the maximum amount of money from poor residents before they are shut off completely. Fifty cents of every dollar collected by DWSD goes directly to finance debt principally owned by wealthy bondholders, big banks and hedge funds.

(Martin, 2017)

Without a progressive water rate in place to insure that all families can afford water, the crisis will continue. The Detroit City Council in 2006 adopted such a plan, the Water Affordability Program, to create a safety net allowing low-income residents to pay on the basis of their income, but the plan was significantly downgraded by DWSD head Victor Mercado, and cut altogether during bankruptcy proceedings. Detroiters, who have been 
fighting for the right to water for years, need a water affordability program enacted and current assistance programs expanded.

The problem of water affordability is by no means unique to Detroit or Flint. In 2015, water was cut off to 25,000 households in Baltimore in a similar assault on low-income people and African Americans; in Cleveland, 44,000 homes were sent shutoff notices in 2016 and over 8000 people lost their homes through foreclosure because of tax liens for non-payment of water bills. Data analysis by Bridge Magazine (Martin, 2017) reports that "some studies have forecasted that water prices could quadruple in the next 20 years", and notes that cities such as Austin, Charlotte, Chicago, San Francisco, and Tucson "have all experienced water rate hikes of over $50 \%$ in the past five years". This suggests that onethird of households in the US may not be able to pay for water by 2020 .

\section{The bigger picture: planetary urbanization}

In the face of water shutoffs, water contamination, and lack of access to clean water, neoliberal narratives seek to marginalize and isolate low-income people as responsible for their own problems or as unfortunate victims of "innocent errors" or decisions for which the corporations and the state take no responsibility. Such narratives serve to legitimize the treatment of poor, black, and immigrant populations in deindustrialized cities as "disposable" and "surplus populations", and to justify the transfer of infrastructural resources out of their control with a goal of future privatization.

Food \& Water Watch, which has helped stop almost forty privatization efforts and fights for local, public, and democratic control of water, conducted a comprehensive survey of the 500 largest US water systems. They found that, on average, private systems charge 59\% more than public systems (Grant and Miles, 2016). Privatized water services not only have higher costs, but also worse services, profit-motivated decision making, and less accountability. This means they cut corners, respond slowly to service requests, and

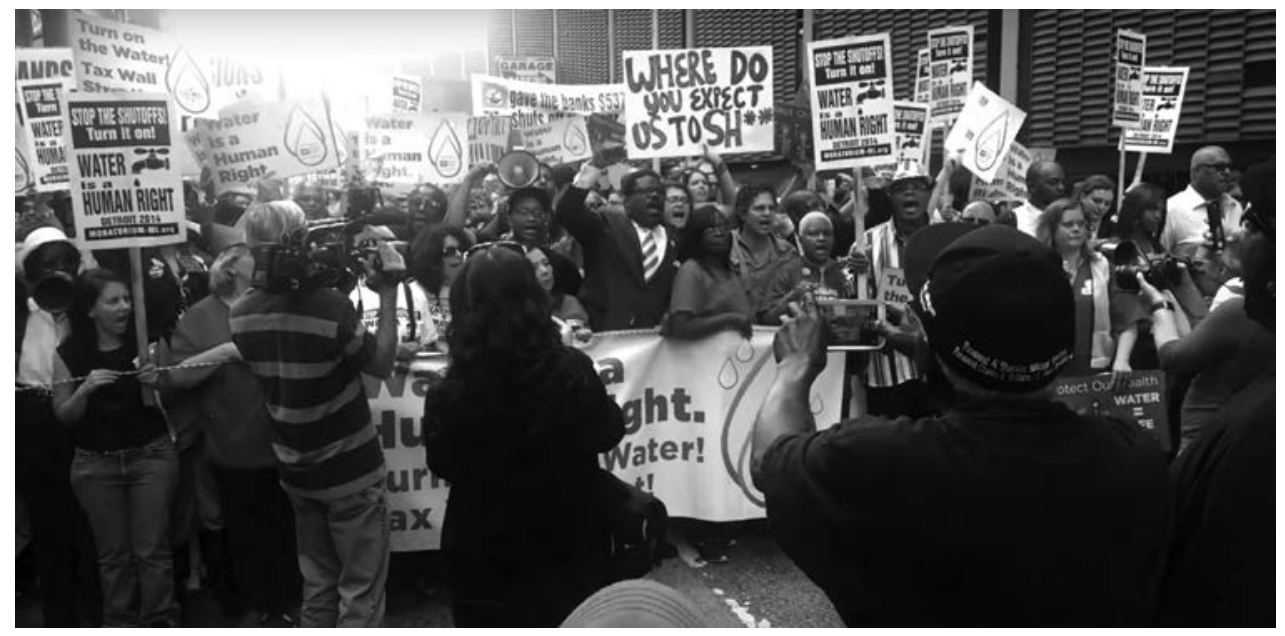

Figure 2.2 National protest against Detroit water shutoffs in downtown Detroit, 18 July 2014. 
let infrastructure deteriorate in order to improve short-term profits. They expand into affluent areas and cut back services in poor areas, where services are needed most, and when problems occur, people have few options.

Moreover, these pushes for privatization are occurring at a time when crumbling water infrastructure is pervasive. Most pipes were laid out in the thirty-year period between 1920 and 1950, including those in cities such as Detroit, Los Angeles, and Chicago. These water infrastructures are all likely to break down at about the same time in the coming years (Cooper, 2009). The plastic and iron industries are currently waging a $\$ 300$ billion lobbying battle to replace the country's deteriorating water and sewer pipes in the next decade, driven by burst pipes, leaks, and public health scares such as occurred in Flint (Tabuchi, 2017). A massive New Deal-style jobs program is needed to get America's old and leaky water infrastructure updated and the nation's drinking water systems able to deliver clean water to everyone. Instead, the Trump administration announced plans in June 2017 to curtail the federal government's role in funding the nation's infrastructure, calling on cities, states, and corporations to take on the cost.

The selloff of public water systems, supported by both major political parties, represents a form of social regression. Privately owned water systems became municipal entities during the nineteenth century in response to the failure of private water companies to adequately maintain infrastructure, meet sanitation needs, and provide services for the masses of workers and residents gathering in cities. It was only through public ownership that sanitary urban conditions and dependable access to water became possible. The turn to neoliberal globalization and a "free market" agenda in the late twentieth century has fostered the return to privately owned water systems and the growing water wars and crises. In 1989, Margaret Thatcher's government privatized all public water and sewerage operations in England; Paris and Berlin privatized their water infrastructure in the 1990s. The International Monetary Fund and World Bank have aggressively insisted on water privatization across Africa, India, South America, Eastern Europe, China, and Saudi Arabia (Barlow, 2007: 36-8; Gaist, 2014; Shiva, 2016), causing ecological havoc and making water inaccessible or unaffordable to millions of mostly poor people. The sale of water systems to powerful water corporations such as Veolia and Suez provides huge profits for a tiny elite that claims the right to own and control water for the world, as if water were a renewable resource to be bought and sold like t-shirts. As scientist and activist Vandana Shiva (2016: 87) argues,

While privatization is generally couched in rhetoric about the disappearing role of the state, what we actually see is increased state intervention in water policy, subverting community control over water resources. Policies imposed by the World Bank, and trade liberalization rules crafted by the World Trade Organization, are creating a sweeping culture of corporate-states all over the world.

Further complicating the struggle of Michigan residents for control over their water, the Swiss-based corporate giant Nestlé Waters has become the largest owner of private water sources in the state. Nestlé has been embroiled for years in lawsuits over its water bottling activities, which include pumping more than 200 gallons of fresh water per minute out of wells in northern Michigan and selling it as Ice Mountain in the Upper Midwest and as Pure Life nationally. In 2017, Nestlé applied to increase its pumping allowance at its well in Evart, Michigan, by $60 \%$. 
Although Evart's city manager supports the increased pumping allowance, claiming that it provides economic development and has minimal ecological impact, thousands of citizens vehemently oppose it, in part because Nestlé pays exactly nothing for the water and only a \$200 annual permit fee to pump from the nine wells it owns or leases. In a state where cities like Flint and Detroit are in water crisis, many are outraged that a giant bottling company can make enormous profits for so little while depleting the Michigan water table, which damages rivers, lakes, and streams, and impacts wetlands, fish populations, and other wildlife. Operating at an immense scale, Nestlé packages an average of 4.8 million bottles of water $a$ day and plans a \$36-million expansion for its Michigan Ice Mountain bottling operations in Stanwood (Friess, 2017).

Not surprisingly, Nestlé has ties to the Snyder administration: Deb Muchmore, the spokesperson in Michigan for Nestlé, is the wife of Dennis Muchmore, Snyder's former chief of staff, who was intimately involved in the Flint water switch. As celebrity filmmaker and Flint activist Michael Moore notes (2016), "The Muchmores have a personal interest in seeing to it that Nestlé grabs as much of Michigan's clean water as possible - especially when cities like Flint in the future are going to need that Ice Mountain". Indeed, the Detroit Free Press reported that in March 2015, Dennis Muchmore proposed spending \$250,000 to buy bottled water from Nestlé or Absopure for the citizens of Flint (Matheny and Egan, 2016).

As previous ecological victories of the 1980s continue to be rolled back by environmental deregulation at the state and national levels, public health and the environment continue to deteriorate. One of the first acts of the Trump administration was to overturn a late Obama-era regulation prohibiting surface-mining operations from dumping waste into nearby waterways. Trump further proposed cutting funding to the Great Lakes Restoration Initiative. The Great Lakes represent $21 \%$ of the world's supply of natural fresh water, especially critical at a time when the world is running out of this precious resource. The Great Lakes Restoration Initiative was intended to clean up giant harmful algae blooms, toxic shipping discharge, and invasive species. In 2014, toxic algae blooms in Lake Erie contaminated water for 400,000 people in Michigan and Ohio and left them without drinking water for three days, while some residents on the Canadian side of Lake Erie had no drinking water for almost two weeks. Because of climate change, such algae blooms are expected to become larger, more frequent, and more toxic. To make matters worse, since 2000, Nestlé has been allowed to package and sell water from the Great Lakes Basin (aquifers feeding the Great Lakes) for billions of dollars in profits. Given the growing dangers to the Great Lakes, the commercialization and export of Great Lakes water is yet another threat to the 26 million people who depend on the Great Lakes Basin for their water supply.

The pathways of capitalist development create dramatic transformations of the spaces around cities, often at a considerable distance from them, including processing plants and subterranean industrial infrastructure. The progressive industrialization and ruination of the hinterland to support the extraction and bottling of water is a major destructive effect of water privatization. Such colonization of the environment moots boundaries between urban settlements and their allegedly non-urban exteriors and impacts millions of people across state and national boundaries. This suggests the need for a new understanding of urbanization that replaces the traditional concept of the city as circumscribed and autonomous. As critical urban theorist Neil Brenner argues, the nineteenth-century concept of the city as bounded and self-sufficient has become obsolete as capitalism produces "intensifying degradation of surrounding landscapes, ecosystems, watersheds, 
rivers, seas and oceans through their intensifying role in supplying cities with fuel, materials, water and food, and in absorbing their waste products" (2017: 217). Brenner urges us to realize that we are witnessing "nothing less than the intensification and extension of capitalist urbanization at all spatial scales, across the planetary space as a whole, including not only the earth's terrestrial surfaces, but the underground, the oceans, and even the atmosphere itself" (2017: 36). To conceptualize "planetary urbanization", in Brenner's terms, is to recognize the way capitalist urbanization has already massively transformed and degraded the environment, causing widespread and ongoing suffering among the world's populations.

Critical urban theory is a way of thinking about urbanization and its future founded on a Marxist critique of capitalism in both spatial and political terms. Rethinking of the urban imaginary began at least as far back as the 1970s with radical scholars such as Henri Lefebvre and David Harvey, among others, who shared a concern over the way that cities under capitalism became key sites for commodification processes. Such processes focus on expanding profits for a tiny percentage of the wealthy upper class even as they lead to global economic crises such as that of 2007-2009, in which, among other effects, millions of people lost their homes. Planetary urbanization points to the need for a vision of urban life beyond capitalism as a structuring principle.

The linked crises in Flint, Detroit, the Great Lakes and many other cities and regions pose the urgent question of a worldwide urban imaginary that takes into account the importance of collective rather than private ownership of resources, responding to social needs rather than capitalist profit-making. Instead of trying to make capitalism "work better" by regulating itself and reining in its own "excessive" greed, it must be recognized that a liberal response such as this fails to see the problem as systemic rather than individual. Capitalism is a system that depends on aggressive commodification and an expanding rate of profit, and regards cities as vehicles of profit for the few in a steadily expanding network of exploitation. Planetary urbanization makes it clear that borders are relatively meaningless, not only between hinterland and urban center, but among regions, nations, and continents.

The continued pillaging and privatizing of water and other public utilities, as part of the dispossession of common assets and publicly owned property for the purpose of capitalist accumulation, will only lead to future catastrophes. Will the fierce resistance movements that have arisen around the globe to the corporate takeover of water be sufficient to stop water privatization and to establish water justice and water democracy? Popular outrage generated by crises such as those produced in Detroit and Flint must ultimately reckon with the rule of profit over the economy as a whole and champion the idea of cities for the benefit of people, where the hopes and dreams of a productive and creative life may be fulfilled. Access to clean water - like the fundamental need for housing, jobs, public transportation, and access to education and healthcare - is a basic human demand, yet its realization ultimately requires the economic and political reorganization of society.

\section{Conclusion}

We cannot afford to let private interests seize and maintain global control of water for their own profit as the world runs out of freshwater and ever-greater numbers of people live without access to clean water or simply cannot afford to pay for it. The potentially irreversible ecological disaster caused by corporate control of the 


\section{Dora Apel}

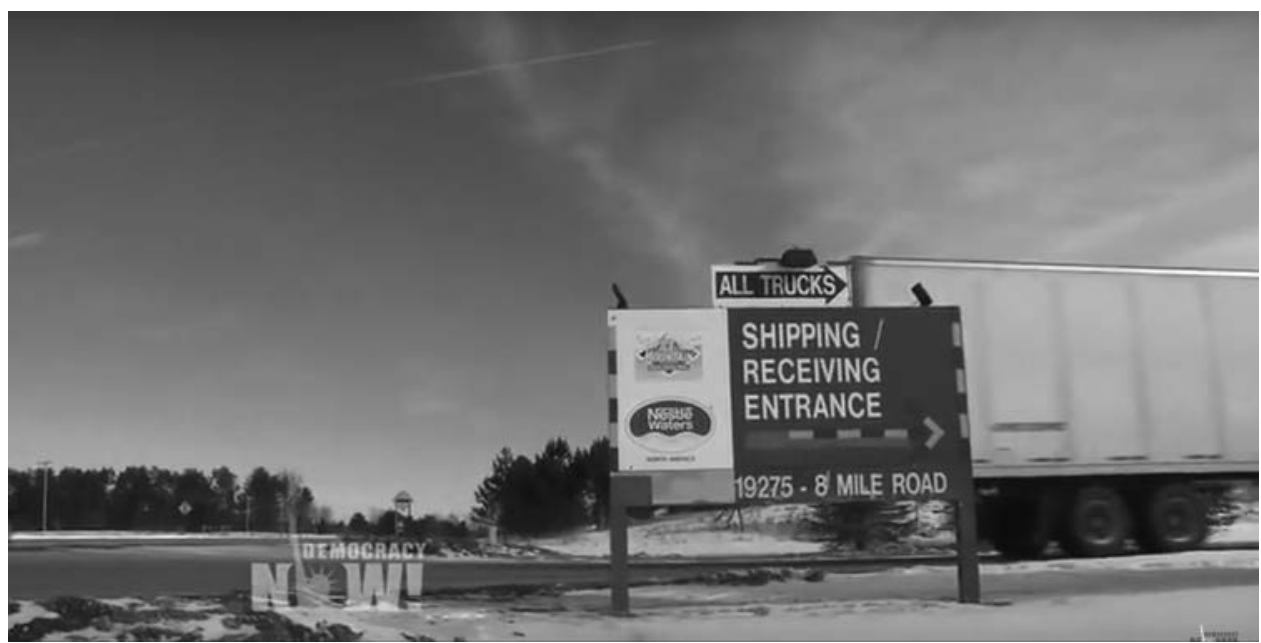

Figure 2.3 Exterior view of the Nestlé Waters Ice Mountain bottling plant near Stanwood, Michigan.

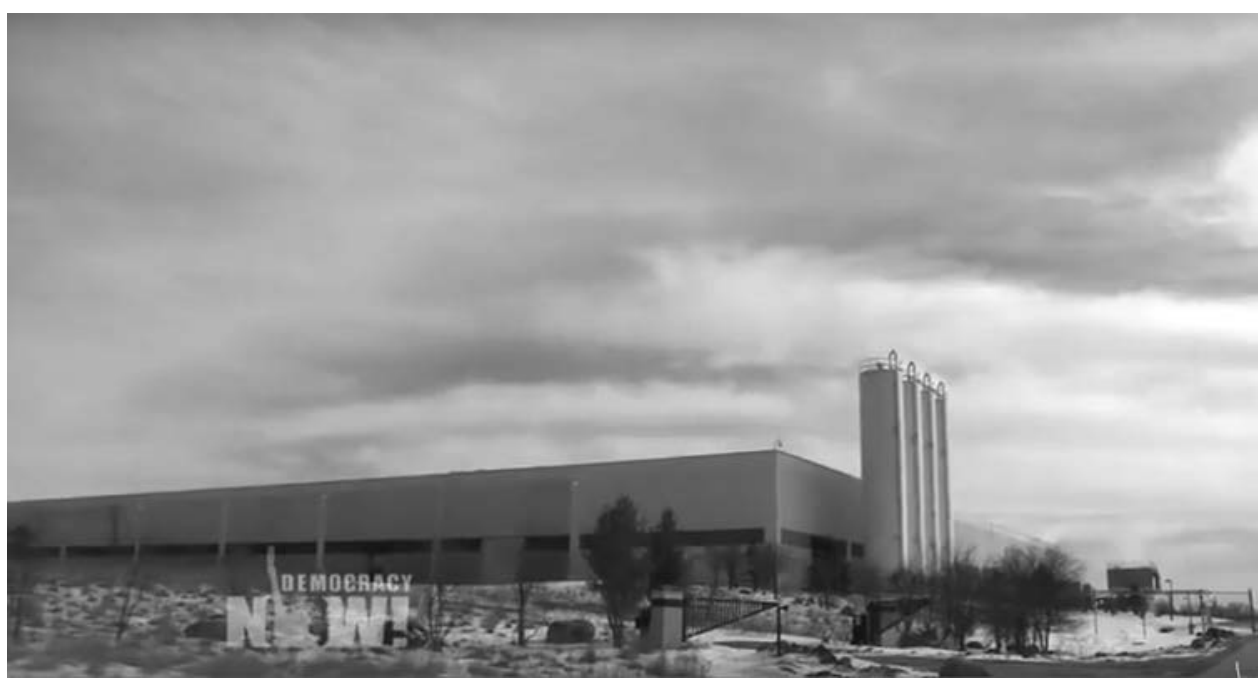

Figure 2.4 Exterior view of the Nestlé Waters Ice Mountain bottling plant near Stanwood, Michigan.

non-replaceable resource of water has positioned the global water crisis at the center of the most pressing challenges we face today: diminishing fresh water, social inequality, and the privatization of public resources and services. The appropriation of water resources dispossesses people of their just share of natural resources and will 
eventually destroy the planet. In response to planetary urbanization, an emancipatory urban imaginary must be based on common public ownership of resources, managed according to need and the public good rather than profit, including the resource that is the basis of all life: water.

\section{References}

Apel, D. (2015) Beautiful Terrible Ruins: Detroit and the Anxiety of Decline. New Brunswick: Rutgers University Press.

Atkinson, S. and Davey, M. (2017) 5 Charged with Involuntary Manslaughter in Flint Water Crisis. The New York Times, 14 June.

Barlow, M. (2007) Blue Covenant: The Global Water Crisis and the Coming Battle for the Right to Water. New York: The New Press.

Brenner, N. (2009) What Is Critical Urban Theory? City 1(2-3): 198-207.

Brenner, N. (2017) Critique of Urbanization: Selected Essays. Basel: Birkhäuser Verlag.

Brewer, J. and White, J. (2016) Questions Emerge over Motives for Ending Flint's Ties to Detroit Water System. World Socialist Web Site, 29 January. Available at: https://www9.wsws.org/en/ articles/2016/01/29/dwsd-j29.html.

Cooper, M. (2009) Aging of Water Mains Is Becoming Hard to Ignore. The New York Times, 17 April.

Delaney, A. (2017) Some Flint Residents Could Face Foreclosure Over Unpaid Water Bills. Huffington Post, 18 May. Available at: http://www.huffingtonpost.com/entry/flint-residentsunpaid-water-bills-foreclosure_us_5909e494e4b05c397684e4ec.

Democracy Now! (2014) Water Is a Human Right: Detroit Residents Seek U.N. Intervention as City Shuts off Taps to Thousands, 24 June. Available at: https://www.democracynow.org/2014/6/24/ water_is_a_human_right_detroit.

Democracy Now! (2016) Thirsty for Democracy: The Poisoning of an American City: Special Report on Flint's Water Crisis, 17 February. Available at: https://www.democracynow.org/2016/2/17/ thirsty_for_democracy_the_poisoning_of.

DeVito, L. (2017) Centers for Disease Control Find Link between Flint Water and Legionnaire's Disease. Detroit Metro Times, 16 February. Available at: http://www.metrotimes.com/table-andbar/archives/2017/02/16/centers-for-disease-control-finds-link-between-flint-water-and-legion naires-disease.

Fonger, R. (2017) Consultant Puts Cost of Flint Water Plant Fixes at \$108 Million. MLive, 7 February. Available at: http://www.mlive.com/news/flint/index.ssf/2017/02/consultants_final_report_puts. $\mathrm{html}$.

Friess, S. (2017) Where Nestlé Guzzles Water, Locals Doubt Claims of Negligible Impact. The New York Times, 24 May.

Gaist, T. (2014) Privatization of Detroit's Water Moving Forward at "Lightning Pace." World Socialist Web Site, 8 April. Available at: https://www.wsws.org/en/articles/2014/04/08/dwsd-a08.html.

Grant, M. and Miles, J. (2016) Lessons from Flint and the Price of Water Privatization. Food and Water Watch, 16 February. Available at: https://www.foodandwaterwatch.org/news/lessons-flintand-price-water-privatization.

Guyette, C. (2017) A Deep Dive into the Source of Flint's Water Crisis: Tunnel Vision. Detroit Metro Times, 19 April.

Hammer, P.J. (2016) The Flint Water Crisis, KWA and Strategic-Structural Racism. Written Testimony Submitted to the Michigan Civil Rights Commission Hearings on the Flint Water Crisis, 18 July. Available at: https://peopleswaterboard.org/wp-content/uploads/2016/07/HammerMCRC-Testimony.pdf.

Hauter, W. (2015) Detroiters Need an Income-Based Approach to Water Bills. Huffington Post, 29 May. Available at: http://www.huffingtonpost.com/wenonah-hauter/detroiters-need-an-income_b_ 6956744.html. 
Kaffer, N. (2016) Why Didn't Flint Treat Its Water? An Answer, At Last. Detroit Free Press, 31 March. Available at: http://www.freep.com/story/opinion/2016/03/30/flint-water-crisis/ $82421546 /$.

Khan, K. (2016) 18 Million People Served by Water Systems with Lead Violations in 2015, Report Says. PBS, 29 June. Available at: http://www.pbs.org/newshour/rundown/18-million-peopleserved-by-water-systems-with-lead-violations-in-2015-report-says/.

Kovac, M. (2015) The Truth about the Detroit Water Shutoffs. Progress Michigan, 9 April. Available at: http://www.truth-out.org/news/item/30118-the-truth-about-the-detroit-water-shutoffs.

Kurth, J., Bridge Magazine, and Detroit Journalism Cooperative. (2017) Detroit Shut Water to 1 in 10 Homes This Year. Yes, That's Progress. Michigan Radio, 5 December. Available at: http:// michiganradio.org/post/detroit-shut-water-1-10-homes-year-yes-s-progress.

Martin, K. (2017) Detroit Water Shutoff Crisis Intensifies under Bill Payment Scheme. World Socialist Web Site, 10 May. Available at: https://www.wsws.org/en/articles/2017/05/10/wate-m10.html.

Matheny, K. and Egan, P. (2016) Nestlé Bottled Water Company Seeks to Take More Michigan Water. Detroit Free Press, 20 November. Available at: http://www.freep.com/story/news/local/michigan/ 2016/11/20/nestl-bottled-water-company-seeks-take-more-michigan-water/93175144/.

Moore, M. (2016) 10 Things They Won't Tell You about the Flint Water Tragedy. But I Will. Huffington Post, 1 February. Available at: http://www.huffingtonpost.com/michael-moore/10things-about-flint-water-tragedy_b_9132150.html.

Nichols, J. (2014) Against Austerity in Detroit: 'Water Is a Human Right'. The Nation, 11 July. Available at: https://www.thenation.com/article/against-austerity-detroit-water-human-right/.

NOVA. (2017) Poisoned Water. PBS, 31 May.

OHCHR. (2014) Detroit: Disconnecting Water from People Who Cannot Pay - An Affront to Human Rights, Say UN Experts. OHCHR, 25 June. Available at: http://www.ohchr.org/EN/NewsEvents/ Pages/DisplayNews.aspx?NewsID=14777\&LangID=E.

Plum, A., Moxley, K., and Zervos, M. (2017) Water Shutoffs Impact Public Health: A Collaborative Study with Henry Ford Health System. We the People of Detroit, 11 April. Available at: https:// wethepeopleofdetroit.com/2017/04/11/water-shutoffs-impact-public-health-a-collaborative-studywith-henry-ford-health-system/.

Shiva, V. (2016) Water Wars: Privatization, Pollution, and Profit. 2nd edn. Berkeley: North Atlantic Books.

Smith, M. and Bosman, J. (2016) Michigan Attorney General Sues 2 Companies Over Flint Water Crisis. The New York Times, 22 June.

Tabuchi, H. (2017) A \$300 Billion Ground War. The New York Times, 11 November.

Veolia. (2015) Flint Michigan: Water Quality Report, 12 March. Available at: http://www.cityofflint. com/wp-content/uploads/Veolia-REPORT-Flint-Water-Quality-201503121.pdf.

White, J. (2014) Regional Authority a Prelude for Privatization of Detroit Water System. World Socialist Web Site, 12 September. Available at: https://www.wsws.org/en/articles/2014/09/12/ dwsd-s12.html.

WJBD. (2017) Nearly 77 Million Served Water from Contaminated Systems, Report Says. WJBD, 2 May. Available at: http://www.wjbdradio.com/health-news/2017/05/02/nearly-77-million-servedwater-from-contaminated-systems-report-says.

WXYZ. (2017) City of Flint Intends to Remain on Detroit's Water Supply. WXYZ, 18 April. Available at: http://www.wxyz.com/news/flint-mayor-karen-weaver-to-give-recommendations-for-watersources. 